\title{
Erratum to: Reducing leachability and bioavailability of soil heavy metals using modified and bare $\mathrm{Al}_{2} \mathrm{O}_{3}$ and $\mathrm{ZnO}$ nanoparticles
}

\author{
Shahriar Mahdavi • Abbas Afkhami
}

Published online: 22 November 2014

(c) Springer-Verlag Berlin Heidelberg 2014

\section{Erratum to: Environ Earth Sci}

\section{DOI 10.1007/s12665-014-3723-6}

The authors would like to correct errors in the original publication as detailed below.

The correct version of the author lists is given here:

Shahriar Mahdavi • Abbas Afkhami

Shahriar Mahdavi

Department of Soil Science, College of Agriculture, Malayer University, Malayer, Iran

e-mail: smahdaviha@yahoo.com;

sh.mahdavi@malayeru.ac.ir

Abbas Afkhami

Department of Analytical Chemistry, College of Chemistry, Bu-Ali Sina University, Hamedan, Iran

The online version of the original article can be found under doi:10.1007/s12665-014-3723-6.

\section{S. Mahdavi ( $\square)$}

Department of Soil Science, College of Agriculture,

Malayer University, Malayer, Iran

e-mail:smahdaviha@yahoo.com; sh.mahdavi@malayeru.ac.ir

A. Afkhami

Department of Analytical Chemistry, College of Chemistry,

Bu-Ali Sina University, Hamedan, Iran 